\title{
GENETIC DIVERSITY IN ARABICA COFFEE GROWN IN POTASSIUM-CONSTRAINED ENVIRONMENT
}

\author{
Diversidade genética em café arábica cultivado em \\ ambiente com restrição de potássio
}

\author{
Waldênia de Melo Moura ${ }^{1}$, Yaska Janaína Bastos Soares², Antônio Teixeira do Amaral Júnior \\ Paulo César de Lima ${ }^{1}$, Hermínia Emília Prieto Martinez ${ }^{4}$, Geraldo de Amaral Gravina ${ }^{3}$
}

\begin{abstract}
Potassium is a source of non-renewable natural resource, and is used in large quantities in coffee fertilization through basically imported formulations in the form of potassium chloride. An alternative to make production systems more sustainable would be obtaining cultivars more efficient in the use of this nutrient. This study aimed to evaluate the genetic diversity among 20 cultivars of coffee, in conditions of low availability of potassium to identify the best combinations for composing future populations to be used in breeding programs. The experiment was arranged in a randomized block design with three replications of nutrient solution. Agronomic characteristics and efficiencies of rooting, absorption, translocation, biomass production and potassium utilization were evaluated. The clustering analysis was based on the unweighted pair group method with arithmetic mean clustering algorithm (UPGMA) and canonical variables. Variability was observed for most treatments. The multivariate procedures produced similar discrimination of genotypes, with the formation of five groups. Hybridizations between the cultivar Icatu Precoce IAC 3283 with cultivars Catuaí Amarelo IAC 62, Araponga MG1, Caturra Vermelho IAC 477, Catuaí Vermelho IAC 15, Rubi MG 1192 and Catucaí 785/15, and between the cultivar Tupi IAC 1669-33 with cultivars Icatu Vermelho IAC 4045, Acaiá Cerrado MG 1474 and Oeiras MG 6851 are the most promising for obtaining segregating populations or heterotic hybrids in breeding programs aiming more efficiency in potassium utilization.
\end{abstract}

Index terms: Coffea arabica, nutritional efficiency, K deficiency, multivariate analysis.

\begin{abstract}
RESUMO
O potássio constitui uma fonte de recurso natural não renovável, e é utilizado em grandes quantidades nas adubações cafeeiras, por meio de formulações, basicamente, importadas na forma de cloreto de potássio. Uma alternativa para tornar os sistemas de produção mais sustentáveis seria a obtenção de cultivares mais eficientes no uso desse nutriente. Assim, neste trabalho, objetivou-se avaliar a divergência genética entre 20 cultivares de café, em condições de baixa disponibilidade de potássio, visando a identificar as melhores combinações para compor futuras populações a serem utilizadas em programas de melhoramento genético. Utilizou-se o delineamento em blocos casualizados, com três repetições em solução nutritiva. Foram avaliadas características morfoagronômicas e as eficiências de enraizamento, de absorção, de translocação, de produção de biomassa e de utilização de potássio. Como estratégias de agrupamentos foram empregados o método hierárquico unweighted pair-group method using arithmetic averages (UPMGA) e a análise de variáveis canônicas. Observou-se variabilidade para a maioria das características avaliadas. Os procedimentos multivariados apresentaram resultados análogos na discriminação de genótipos com a formação de cinco grupos. As hibridações entre as cultivares Icatu Precoce IAC 3283 com as cultivares Catuaí Amarelo IAC 62, Araponga MG1, Caturra Vermelho IAC 477, Catuaí Vermelho IAC 15, Rubi MG1192 e Catucaí 785/15, e entre a cultivar Tupi IAC 1669-33 com as cultivares Icatu Vermelho IAC 4045, Acaiá Cerrado MG 1474 e Oeiras MG 6851 são consideradas as mais promissoras na obtenção de populações segregantes ou híbridos heteróticos para maior eficiência no uso de potássio.
\end{abstract}

Termos para indexação: Coffea arabica, eficiência nutricional, deficiência de K, análise multivariada.

\section{INTRODUCTION}

Brazilian coffee has great economic and social importance in the domestic and global scenarios. It is a growing market, reaching 91 billion dollars per year. Brazil accounts for about $35 \%$ of world coffee production, being one of the largest producers, exporters and consumers worldwide - with turnover of 6.5 billion dollars in 2012, becoming the main commodity of the domestic trade balance (FAO, 2013). In Brazil, coffee is grown in highly weathered soils with low fertility and acute potassium, calcium and magnesium deficiencies. To achieve high

${ }^{1}$ Empresa de Pesquisa Agropecuária de Minas Gerais/EPAMIG - Unidade Regional Zona da Mata/UREZM - Vila Gianetti, $46 / 47$ - Campus da UFV 36570-000 - Viçosa - MG - Brasil - waldenia@epamig.ufv.br

${ }^{2}$ Comissão Executiva do Plano da Lavoura Cacaueira/CEPLAC - Ilhéus - BA - Brasil

3Universidade Estadual Norte Fluminense Darcy Ribeiro/UENF - Campos dos Goytacazes - RJ - Brasil

${ }^{4}$ Universidade Federal de Viçosa/UFV - Viçosa - MG - Brasil

Received in august 19, 2014 and approved in september 29, 2014

Ciênc. Agrotec., Lavras, v.39, n.1, p.23-31, jan./fev., 2015 
yields, large quantities of chemical fertilizers are used, making up about $40 \%$ of the total production costs (MAPA, 2012).

Potassium is a non-renewable natural resource and is used in fertilizers in the form of potassium chloride. It mainly comes from imported formulations, which increases the production. Potassium is the second most important nutrient for coffee crops, playing an important role in the synthesis of proteins, carbohydrates and adenosine triphosphate (ATP), in osmotic regulation and tolerance to pests and diseases through its effect on the strength and permeability of plasma membranes (Marschner, 2012). It participates in the coffee plants reproductive development, yield and bean size (Laviola et al., 2006; Clemente et al., 2013). Potassium also contributes to beverage quality by activating the polyphenol oxidase enzyme in coffee beans (Guimarães et al., 2011). Therefore, there is a need for alternatives that can contribute to the sustainability of coffee cultivation in Brazilian soils and studies involving mineral nutrition and breeding for selection of genotypes that are more efficient at $\mathrm{K}$ utilization are crucial.

According Gabelman and Gerloff (1983), absorption, transport and redistribution of nutrients in plants are under genetic control, thus the possibility exists to improve and/or select cultivars for more efficient utilization of nutrients. Nutritional efficiency refers to the ability of a genotype to obtain high yields in nutrient-poor soils (Graham, 1984). However, to avoid the selection of plants with high nutrient utilization efficiency but with low yields, Siddiqi and Glass (1981) proposed a modified approach to the estimation of the utilization efficiency index which is the ratio between square biomass and tissue nutrient concentration.

Studies with coffee have demonstrated genetic diversity among cultivars for efficiency of absorption, transport and utilization of several nutrients (Amaral et al., 2011a; Amaral et al., 2011b; Pedrosa et al., 2013 and Tomaz et al., 2008). However these studies considered the association of macronutrients, especially nitrogen, phosphorus and potassium and/or micronutrients such as boron, copper and zinc, with adequate fertilization, it is then necessary to evaluate the nutritional efficiency for each nutrient separately. Capitalizing on these genotypic differences is the basis for breeding programs and is vital for guiding crossings aiming at increasing efficiency in the uptake, translocation and utilization of potassium by coffee, plants which can be measured by multivariate methods.

Multivariate methods have been successfully applied to estimate the genetic divergence based on agronomic traits of coffee. Principal component analysis, canonical variables and clustering methods have been reported for Arabica coffee (Dias et al., 2005; Guedes et al., 2013; Silva et al., 2013; Teixeira et al., 2013) and for Conilon and Robusta coffee analyses (Fonseca et al., 2006; Ivoglo et al., 2008; Rocha et al., 2013).

The objective of this study was to evaluate the genetic divergence among 20 coffee cultivars in potassium-constrained conditions and identify the most promising combinations for future breeding programs aiming to produce cultivars with greater efficiency potassium utilization.

\section{MATERIAL AND METHODS}

The experiment was conducted in a greenhouse at the Plant Science Department (DFT) of the Federal University of Viçosa, Minas Gerais, in static aerated nutrient solution containing low potassium rate (1.5 mmol L $\left.{ }^{-1}\right)$. A randomized block design was used with twenty coffee cultivars (Table 1) and three replicates. The plots consisted of two plants grown in pots with nutrient solution.

The twenty coffee cultivars were sown in plastic trays containing sand pretreated with $0.1 \mathrm{~N} \mathrm{HCl}$. Weekly irrigations were performed until the seedlings reached the "jaguar ear" stage when they were transplanted into plastic containers containing $8.0 \mathrm{~L}$ of Hoagland and Arnon (1950) nutrient solution. A Schultz compressor was used to oxygenate the nutrient solution and the solution volume in the containers were completed with deionized water to a volume of $8.0 \mathrm{~L}$. The $\mathrm{pH}$ was weekly adjusted to $5.5-6.5$ with $\mathrm{HCl}(1.0 \mathrm{~N})$ and $\mathrm{NaOH}(1.0 \mathrm{~N})$ and the solutions were replaced based on the electrical conductivity (EC), when depletion reached $30 \%$ of the initial EC. The nutrient solution was replaced twice.

The following agronomic characteristics were evaluated: plant height $(\mathrm{PH})-$ measured from the base of the orthotropic branch to the plant apex, in m; number of leaves (NL) - counting the leaves in the whole plant; number of nodes (NN) - counting the nodes in the orthotropic branch; stem diameter (SD) - using digital calipers at the base of the orthotropic branch, in $\mathrm{mm}$; leaf area (LA) - based on the total number of leaves using a calibrated leaf area meter (Delta-T Devices Ltd., Burwell, Cambridge); and internode length (IL) - the ratio plant height:number of nodes. 
Table 1 - Cultivars of coffee (Coffea arabica L.) and genetic origin evaluated.

\begin{tabular}{ll}
\hline \multicolumn{1}{c}{ Cultivars } & \multicolumn{1}{c}{ Genetic origin } \\
\hline 1 - Catuaí Amarelo IAC 62 & Caturra Amarelo IAC 476-11 x Mundo Novo IAC 374-19 \\
2 - Paraíso MG H 419-1 & Caturra Amarelo IAC 30 x Híbrido de Timor UFV 445-46 \\
3 - Icatu Vermelho IAC 4045 & Coffea canephora x Bourbon Vermelho \\
4 - Obatã IAC 1669/20 & Villa Sarchi x Híbrido de Timor \\
5 - Caturra Amarelo IAC 476 & Mutation of the cultivar Caturra Vermelho IAC 447 \\
6 - IPR 102 & Icatu x (Catuaí Amarelo IAC 66 x Catuaí Vermelho IAC 99) \\
7 - Catuaí Vermelho IAC 15 & Caturra Amarelo IAC 476-11 x Mundo Novo \\
8 - Rubi MG 1192 & Catuaí x Mundo Novo \\
9 - IPR 103 & Icatu x (Catuaí Amarelo IAC 66 x Catuaí Vermelho IAC 99) \\
10 - Araponga MG1 & Caturra Amarelo IAC 86 x Híbrido de Timor UFV 446-08 \\
11 - Topázio MG 1190 & Catuaí Amarelo x Mundo Novo \\
12 - San Ramon & Progeny C 1034-4 introduced of the Costa Rica \\
13 - Icatu Precoce IAC 3282 & Icatu Vermelho x Bourbon Amarelo \\
14 - Tupi IAC 1669-33 & Villa Sarchi x Híbrido de Timor \\
15 - Catucaí 785/15 & Icatu Vermelho x Catuaí Vermelho \\
16 - Acaiá Cerrado MG 1474 & Acaiá 474-1, selection of the Mundo Novo \\
17 - Oeiras MG 6851 & Híbrido CIFC HW 26/5 (Caturra Vermelho x Híbrido de Timor) \\
18 - São Bernardo & Mutation of the coffee Típica \\
19 - Pau Brasil MG1 & Catuaí Vermelho IAC 15 x Híbrido de Timor UFV 442/34 \\
20 - Caturra Vermelho IAC447 & Mutation of the cultivar Bourbon Vermelho \\
\hline
\end{tabular}

The plants were separated into roots, stems and leaves, and dried in an oven with forced air circulation at $70{ }^{\circ} \mathrm{C}$ for 72 hours. The dried samples were weighed and the following estimates obtained: root dry mass (RDM); stem dry mass (SDM); and leaf dry mass (LDM). Dry plant materials were ground with a Wiley mill to pass through a 20-mesh sieve and samples were analyzed in the Leaf Analysis Laboratory of the Federal University of Viçosa (UFV) to determine the nutrient levels. The $\mathrm{K}$ levels in the plant parts were used to determine the $\mathrm{K}$ contents by multiplying the $\mathrm{K}$ levels by the dry mass of each plant part.

The utilization efficiency indices were estimated on the basis of dry mass and $\mathrm{K}$ levels, according to Siddiqi and Glass (1981): a) rooting efficiency $(\mathrm{RE})=(\mathrm{g}$ of root dry matter $)^{2} / \mathrm{mg}$ of $\mathrm{K}$ in the plant; b) potassium absorption efficiency (KAE) $=\mathrm{mg}$ of $\mathrm{K}$ in the plant/ $\mathrm{g}$ root dry matter; c) potassium translocation efficiency $(\mathrm{KTE})=\mathrm{mg}$ of $\mathrm{K}$ in the aerial part/ $\mathrm{mg}$ of $\mathrm{K}$ in the plant; d) biomass efficiency $(\mathrm{BE})=(\mathrm{g}$ dry matter of the aerial part $)^{2} / \mathrm{mg}$ of $\mathrm{K}$ in the aerial part; and e) potassium utilization efficiency $(\mathrm{KUE})=(\mathrm{g} \text { dry matter })^{2} / \mathrm{mg}$ of $\mathrm{K}$ in the plant. Data were subjected to analysis of variance and means were compared by the Scott-Knott test, at 5\% probability. The multivariate analysis was performed using the Unweighted Pair-Group Method Using an Arithmetic Average (UPGMA) based on the genetic dissimilarity matrix estimated by the Generalized Mahalanobis Distance and canonical variables. The relative importance of each trait was calculated by the Singh's method (Singh, 1981). The analyses were performed using the GENES software (Cruz, 2013) and the hierarchic clustering (function hclust) of the standard R software.

\section{RESULTS AND DISCUSSION}

The coffee cultivars showed variability for most caracteristics evaluated $(\mathrm{P}<0.05)$, and only root/ shoot ratio was not significantly different (Table 2).

Cultivars Icatu Vermelho IAC 4045, Icatu Precoce IAC 3282 and Acaiá Cerrado MG 1474 showed the highest means for plant height and internode length, while San Ramon and São Bernardo presented the lowest values for these traits (Table 2). This result was expected because 
these cultivars have genetic factors that determine plant height and internode length - Icatu Vermelho IAC 4045 and Icatu Precoce IAC 3282 are tall cultivars, whereas San Ramon and São Bernardo have very short height (Carvalho, 2008).

The highest means for leaf area, number of leaves and number of nodes were observed for cultivars Catuaí Amarelo IAC 62, Caturra Amarelo IAC 476, Catuaí Vermelho IAC 15, Rubi MG 1192, Pau Brasil MG 1 and Caturra Vermelho IAC 477 showed (Table 2). A higher rate of leaf growth in seedlings is desirable, since the leaves convert light energy into chemical energy essential for plant growth and development (Marenco; Lopes, 2005). Besides, increased number of nodes can lead to a larger number of primary plagiotropic branches and greater production of secondary branches, thus benefiting the production (Tomaz et al., 2005).
Stem diameter means were highest in the cultivars Obatã IAC 1669/20, Caturra Amarelo IAC 476, IPR 102, Catuaí Vermelho IAC 15, Rubi MG 1192, Araponga MG 1, Tupi IAC 1669-33, Catucaí 785/15 and Caturra Vermelho IAC 477 (Table 2). Studies carried out during the coffee juvenile stage have shown that this is an important trait for discrimination of coffee genotypes and was highly correlated with vigor and number of nodes of the first plagiotropic branch (Teixeira et al., 2013). The largest dry matter productions of root, stem and leaf were obtained by cultivars Obatã IAC 1669/20, Caturra Amarelo IAC 476, IPR 102, Rubi MG 1192, Araponga MG 1, Tupi IAC 1669-33, Catucaí $785 / 15$ and Caturra Vermelho IAC 477 (Table 2), which may be associated with the highest means per number of leaves $(\mathrm{NL})$, number of nodes $(\mathrm{NN})$ and leaf area (LA).

Table 2 - Mean plant height (PH), number of leaves (NL), number of nodes (NN), internode length (IL), stem diameter (SD), leaf area (LA), leaf dry mass (LDM), evaluated in cultivars of coffee grown in nutrient solution with low potassium $\left(1.5 \mathrm{mmol} \mathrm{L}^{-1}\right)$.

\begin{tabular}{|c|c|c|c|c|c|c|c|c|c|}
\hline Cutivars & $\begin{array}{l}\mathrm{PH} \\
(\mathrm{cm})\end{array}$ & NL & $\mathrm{NN}$ & $\begin{array}{c}\mathrm{IL} \\
(\mathrm{cm})\end{array}$ & $\begin{array}{l}\mathrm{SD} \\
(\mathrm{cm})\end{array}$ & $\begin{array}{c}\text { LA } \\
\left(\mathrm{cm}^{2}\right)\end{array}$ & $\begin{array}{l}\text { RDM } \\
(\mathrm{g})\end{array}$ & $\begin{array}{c}\text { SDM } \\
(\mathrm{g})\end{array}$ & $\begin{array}{c}\text { LDM } \\
(\mathrm{g})\end{array}$ \\
\hline Catuaí Ama & $47.4 \mathrm{~B}$ & $36.3 \mathrm{~A}$ & $12.3 \mathrm{~A}$ & $3.8 \mathrm{~B}$ & $0.58 \mathrm{~B}$ & $2289.7 \mathrm{~A}$ & $3.0 \mathrm{~B}$ & $5.2 \mathrm{~A}$ & $11.3 \mathrm{~A}$ \\
\hline Paraíso M & $42.3 \mathrm{~B}$ & $33.3 \mathrm{~B}$ & $12.0 \mathrm{~A}$ & $3.6 \mathrm{~B}$ & $8 \mathrm{C}$ & $1920.7 \mathrm{~A}$ & $3.3 \mathrm{~A}$ & $3.8 \mathrm{~B}$ & $09.6 \mathrm{~A}$ \\
\hline Icatu Vermelho & $55.8 \mathrm{~A}$ & $27.0 \mathrm{~B}$ & $12.0 \mathrm{~A}$ & $4.6 \mathrm{~A}$ & $0.46 \mathrm{C}$ & $1435.3 \mathrm{C}$ & $2.5 \mathrm{~B}$ & $4.0 \mathrm{~B}$ & $06.8 \mathrm{C}$ \\
\hline Obatã IAC & $42.3 \mathrm{~B}$ & $33.0 \mathrm{~B}$ & $11.7 \mathrm{~B}$ & $3.6 \mathrm{~B}$ & $0.65 \mathrm{~A}$ & $1938.4 \mathrm{~A}$ & $4.0 \mathrm{~A}$ & $6.3 \mathrm{~A}$ & $10.8 \mathrm{~A}$ \\
\hline Caturra Amarelo IAC476 & $43.4 \mathrm{~B}$ & $41.0 \mathrm{~A}$ & $12.0 \mathrm{~A}$ & $3.6 \mathrm{~B}$ & $0.67 \mathrm{~A}$ & $2064.3 \mathrm{~A}$ & $3.5 \mathrm{~A}$ & $1 \mathrm{~A}$ & $11.0 \mathrm{~A}$ \\
\hline IPR & $42.3 \mathrm{~B}$ & 38. & $11.2 \mathrm{~B}$ & 3. & $0.61 \mathrm{~A}$ & 198 & & & $0.7 \mathrm{~A}$ \\
\hline Catuaí Vermelho IAC 15 & $44.8 \mathrm{~B}$ & $37.0 \mathrm{~A}$ & $12.7 \mathrm{~A}$ & $3.5 \mathrm{~B}$ & $0.57 \mathrm{~B}$ & $2181.2 \mathrm{~A}$ & $3.2 \mathrm{~B}$ & $5.0 \mathrm{~A}$ & $10.0 \mathrm{~A}$ \\
\hline Rubi MG 1192 & $42.2 \mathrm{~B}$ & $38.0 \mathrm{~A}$ & $12.8 \mathrm{~A}$ & $3.3 \mathrm{C}$ & $0.65 \mathrm{~A}$ & $2148.1 \mathrm{~A}$ & $3.9 \mathrm{~A}$ & $5.6 \mathrm{~A}$ & $11.2 \mathrm{~A}$ \\
\hline IPR & $36.8 \mathrm{C}$ & $28.8 \mathrm{~B}$ & $11.5 \mathrm{~B}$ & $3.2 \mathrm{C}$ & $0.48 \mathrm{C}$ & $1777.5 \mathrm{~B}$ & $2.6 \mathrm{~B}$ & $2.7 \mathrm{C}$ & $08.5 \mathrm{~B}$ \\
\hline Araponga $\mathrm{I}$ & $40.7 \mathrm{~B}$ & $34.0 \mathrm{~B}$ & $11.8 \mathrm{~B}$ & $3.5 \mathrm{C}$ & $0.65 \mathrm{~A}$ & 204 & $3.9 \mathrm{~A}$ & $4.7 \mathrm{~A}$ & $10.5 \mathrm{~A}$ \\
\hline Topázio & $43.9 \mathrm{~B}$ & $40.2 \mathrm{~A}$ & $11.7 \mathrm{~B}$ & $3.8 \mathrm{~B}$ & $0.52 \mathrm{~B}$ & 20 & $2.9 \mathrm{~B}$ & $4.3 \mathrm{~B}$ & $10.3 \mathrm{~A}$ \\
\hline San R & $27.0 \mathrm{D}$ & $29.5 \mathrm{~B}$ & $12.2 \mathrm{~A}$ & $2.3 \mathrm{E}$ & $0.39 \mathrm{C}$ & $1236.3 \mathrm{C}$ & $2.0 \mathrm{~B}$ & $1.6 \mathrm{C}$ & $06.0 \mathrm{C}$ \\
\hline Icatu Precoce & $61.0 \mathrm{~A}$ & $35.0 \mathrm{~A}$ & 12 & $4.9 \mathrm{~A}$ & $0.56 \mathrm{~B}$ & 162 & $2.9 \mathrm{~B}$ & $5.3 \mathrm{~A}$ & $08.4 \mathrm{~B}$ \\
\hline Tupi IAC 16 & $36.6 \mathrm{C}$ & $41.5 \mathrm{~A}$ & 11 & $3.3 \mathrm{C}$ & $0.71 \mathrm{~A}$ & $1971.8 \mathrm{~A}$ & $3.7 \mathrm{~A}$ & $6.2 \mathrm{~A}$ & $11.1 \mathrm{~A}$ \\
\hline Catucaí 785/15 & $37.9 \mathrm{C}$ & $40.3 \mathrm{~A}$ & 11 & $3.2 \mathrm{C}$ & $0.71 \mathrm{~A}$ & $1891.4 \mathrm{~A}$ & & $5.0 \mathrm{~A}$ & $10.3 \mathrm{~A}$ \\
\hline Acaiá Cerrad & $59.8 \mathrm{~A}$ & $30.2 \mathrm{~B}$ & & $4.7 \mathrm{~A}$ & & 152 & $3.0 \mathrm{~B}$ & $5.3 \mathrm{~A}$ & $07.9 \mathrm{~B}$ \\
\hline Oeiras MG 6851 & $42.1 \mathrm{~B}$ & $28.3 \mathrm{~B}$ & $11.2 \mathrm{~B}$ & $3.8 \mathrm{~B}$ & & $1727.5 \mathrm{~B}$ & $2.5 \mathrm{~B}$ & $3.8 \mathrm{~B}$ & $09.3 \mathrm{~A}$ \\
\hline São Bernardo & $33.8 \mathrm{C}$ & $40.7 \mathrm{~A}$ & & $2.9 \mathrm{D}$ & $0.54 \mathrm{~B}$ & & $2.8 \mathrm{~B}$ & $3.3 \mathrm{~B}$ & $09.8 \mathrm{~A}$ \\
\hline Pau Brasil MG1 & $38.9 \mathrm{~B}$ & $36.7 \mathrm{~A}$ & $12.0 \mathrm{~A}$ & $3.2 \mathrm{C}$ & $0.58 \mathrm{~B}$ & $1892.3 \mathrm{~A}$ & $2.8 \mathrm{~B}$ & $4.5 \mathrm{~A}$ & $10.0 \mathrm{~A}$ \\
\hline Caturra Vermelho IAC 477 & $41.9 \mathrm{~B}$ & $36.3 \mathrm{~A}$ & $12.3 \mathrm{~A}$ & $3.4 \mathrm{C}$ & $0.64 \mathrm{~A}$ & $2071.3 \mathrm{~A}$ & $3.5 \mathrm{~A}$ & $4.9 \mathrm{~A}$ & $10.5 \mathrm{~A}$ \\
\hline Média & 43.04 & 35.3 & 11.9 & 3.6 & 0.57 & 1892.3 & 3.2 & 4.7 & 9.7 \\
\hline CV $(\%)$ & 7.09 & 10.5 & 4.6 & 5.7 & 10.3 & 9.9 & 14.9 & 15.1 & 10.3 \\
\hline
\end{tabular}

Means followed by the same letters in the columns are not significantly different by the Scott-Knot test, at 5\% probability. 
Cultivars Obatã IAC 1669/20, Caturra Amarelo IAC 476, IPR 102, Rubi MG 1192, Araponga MG 1, Tupi IAC 1669-33, Catucaí 785/15 and Caturra Vermelho IAC 477 showed the highest efficiencies of rooting, biomass production and potassium utilization and, although less efficient in the uptake and translocation of this element (Table 3), they showed great ability to utilize the K absorbed. Similar behavior was observed for cultivar IPR 102 in an environment with both low and adequate zinc rates (Pedrosa et al., 2013). However, at low levels of macro and micronutrient fertilization, the cultivar Rubi was the most efficient in using these nutrients for leaf production (Amaral et al., 2011a).
On the other hand, San Ramon was less efficient in utilizing potassium for biomass production, were efficient in the uptake and translocation of $\mathrm{K}$, demonstrating limited ability of these cultivars to convert the absorbed and translocated potassium into dry matter (Table 3). This cultivar also showed low efficiency in utilizing zinc (Pedrosa et al., 2013). The diversity of behavior among the coffee cultivars involves several physiological, morphological and biochemical mechanisms that may limit the translocation of the absorbed nutrient to the shoot, constituting the basis of genotypic differences in nutritional efficiency (Gabelman; Gerlof, 1983). This demonstrates the complexity of cultivar selection when taking the traits in isolation, i.e., based on univariate analysis.

Table 3 - Mean rooting efficiency (RE), potassium absorption efficiency (KAE), potassium translocation efficiency (KTE), biomass efficiency (BE), potassium utilization efficiency (KUE), root/shoot ratio (RSR) evaluated in cultivars of coffee grown in nutrient solution with low potassium $\left(1.5 \mathrm{mmol} \mathrm{L}^{-1}\right)$.

\begin{tabular}{ccccccc}
\hline Cutivars & $\begin{array}{c}\text { RE } \\
\left(\mathrm{g}^{2} \mathrm{mg}^{-1}\right)\end{array}$ & $\begin{array}{c}\text { KAE } \\
\left(\mathrm{mgg}^{-1}\right)\end{array}$ & $\begin{array}{c}\text { KTE } \\
\left(\mathrm{mgmg}^{-1}\right)\end{array}$ & $\begin{array}{c}\mathrm{BE} \\
\left(\mathrm{g}^{2} \mathrm{mg}^{-1}\right)\end{array}$ & $\begin{array}{c}\text { KUE } \\
\left(\mathrm{g}^{2} \mathrm{mg}^{-1}\right)\end{array}$ & $\begin{array}{c}\text { RSR } \\
\left(\mathrm{gg}^{-1}\right)\end{array}$ \\
\hline Catuaí Amarelo IAC 62 & $0.04 \mathrm{~B}$ & $78.08 \mathrm{~A}$ & $0.88 \mathrm{~A}$ & $1.44 \mathrm{~B}$ & $1.76 \mathrm{~B}$ & $0.18 \mathrm{~A}$ \\
Paraíso MG H 419-1 & $0.06 \mathrm{~B}$ & $54.73 \mathrm{C}$ & $0.80 \mathrm{~B}$ & $1.30 \mathrm{~B}$ & $1.61 \mathrm{~B}$ & $0.24 \mathrm{~A}$ \\
Icatu Vermelho IAC 4045 & $0.05 \mathrm{~B}$ & $53.36 \mathrm{C}$ & $0.83 \mathrm{~A}$ & $1.09 \mathrm{~B}$ & $1.37 \mathrm{~B}$ & $0.23 \mathrm{~A}$ \\
Obatã IAC 1669/20 & $0.08 \mathrm{~A}$ & $50.06 \mathrm{C}$ & $0.79 \mathrm{~B}$ & $1.88 \mathrm{~A}$ & $2.24 \mathrm{~A}$ & $0.23 \mathrm{~A}$ \\
Caturra Amarelo IAC476 & $0.07 \mathrm{~A}$ & $53.68 \mathrm{C}$ & $0.79 \mathrm{~B}$ & $2.00 \mathrm{~A}$ & $2.29 \mathrm{~A}$ & $0.21 \mathrm{~A}$ \\
IPR 102 & $0.08 \mathrm{~A}$ & $48.39 \mathrm{C}$ & $0.77 \mathrm{~B}$ & $1.90 \mathrm{~A}$ & $2.24 \mathrm{~A}$ & $0.24 \mathrm{~A}$ \\
Catuaí Vermelho IAC 15 & $0.06 \mathrm{~B}$ & $51.16 \mathrm{C}$ & $0.83 \mathrm{~A}$ & $1.66 \mathrm{~A}$ & $2.03 \mathrm{~A}$ & $0.21 \mathrm{~A}$ \\
Rubi MG 1192 & $0.09 \mathrm{~A}$ & $45.88 \mathrm{C}$ & $0.76 \mathrm{~B}$ & $2.06 \mathrm{~A}$ & $2.39 \mathrm{~A}$ & $0.24 \mathrm{~A}$ \\
IPR 103 & $0.05 \mathrm{~B}$ & $53.00 \mathrm{C}$ & $0.80 \mathrm{~B}$ & $1.14 \mathrm{~B}$ & $1.39 \mathrm{~B}$ & $0.23 \mathrm{~A}$ \\
Araponga MG1 & $0.08 \mathrm{~A}$ & $46.43 \mathrm{C}$ & $0.75 \mathrm{~B}$ & $1.78 \mathrm{~A}$ & $2.09 \mathrm{~A}$ & $0.25 \mathrm{~A}$ \\
Topázio MG 1190 & $0.05 \mathrm{~B}$ & $60.06 \mathrm{C}$ & $0.83 \mathrm{~A}$ & $1.47 \mathrm{~B}$ & $1.76 \mathrm{~B}$ & $0.20 \mathrm{~A}$ \\
San Ramon & $0.03 \mathrm{~B}$ & $78.07 \mathrm{~A}$ & $0.82 \mathrm{~A}$ & $0.61 \mathrm{C}$ & $0.76 \mathrm{C}$ & $0.23 \mathrm{~A}$ \\
Icatu Precoce IAC 3282 & $0.05 \mathrm{~B}$ & $56.64 \mathrm{C}$ & $0.86 \mathrm{~A}$ & $1.34 \mathrm{~B}$ & $1.68 \mathrm{~B}$ & $0.21 \mathrm{~A}$ \\
Tupi IAC 1669-33 & $0.07 \mathrm{~A}$ & $53.81 \mathrm{C}$ & $0.78 \mathrm{~B}$ & $1.93 \mathrm{~A}$ & $2.23 \mathrm{~A}$ & $0.22 \mathrm{~A}$ \\
Catucaí 785/15 & $0.08 \mathrm{~A}$ & $49.58 \mathrm{C}$ & $0.78 \mathrm{~B}$ & $1.69 \mathrm{~A}$ & $2.05 \mathrm{~A}$ & $0.25 \mathrm{~A}$ \\
Acaiá Cerrado MG 1474 & $0.06 \mathrm{~B}$ & $54.12 \mathrm{C}$ & $0.84 \mathrm{~A}$ & $1.29 \mathrm{~B}$ & $1.64 \mathrm{~B}$ & $0.23 \mathrm{~A}$ \\
Oeiras MG 6851 & $0.04 \mathrm{~B}$ & $60.73 \mathrm{C}$ & $0.84 \mathrm{~A}$ & $1.36 \mathrm{~B}$ & $1.63 \mathrm{~B}$ & $0.19 \mathrm{~A}$ \\
São Bernardo & $0.05 \mathrm{~B}$ & $63.29 \mathrm{~B}$ & $0.84 \mathrm{~A}$ & $1.20 \mathrm{~B}$ & $1.48 \mathrm{~B}$ & $0.21 \mathrm{~A}$ \\
Pau Brasil MG1 & $0.04 \mathrm{~B}$ & $64.05 \mathrm{~B}$ & $0.85 \mathrm{~A}$ & $1.42 \mathrm{~B}$ & $1.71 \mathrm{~B}$ & $0.19 \mathrm{~A}$ \\
Caturra Vermelho IAC 477 & $0.07 \mathrm{~A}$ & $48.47 \mathrm{C}$ & $0.80 \mathrm{~B}$ & $1.80 \mathrm{~A}$ & $2.16 \mathrm{~A}$ & $0.22 \mathrm{~A}$ \\
\hline Média & 0.06 & 56.18 & 0.81 & 1.52 & 1.82 & 0.22 \\
CV (\%) & 27.36 & 16.64 & 3.74 & 18.10 & 16.81 & 17.79 \\
\hline
\end{tabular}

Means followed by the same letters in the columns are not significantly different by the Scott-Knot test, at 5\% probability. 
Therefore, considering all the traits analyzed by the multivariate techniques and using the Mahalanobis distance as a dissimilarity measure, it was found that the most dissimilar pairs of cultivars were the combinations involving the cultivar Icatu Precoce IAC 3282 (Figure 1). The pairs of cultivars with larger genetic distances were: San Ramon with cultivars Icatu Precoce IAC 3282, Icatu Vermelho IAC 4045 and Acaiá Cerrado MG 1474; Icatu Precoce IAC 3282 with cultivars IPR 103 and Oeiras MG 6851 . However, one should be careful in choosing these combinations, as most of them did not involve K-efficient cultivars (Table 2 ).

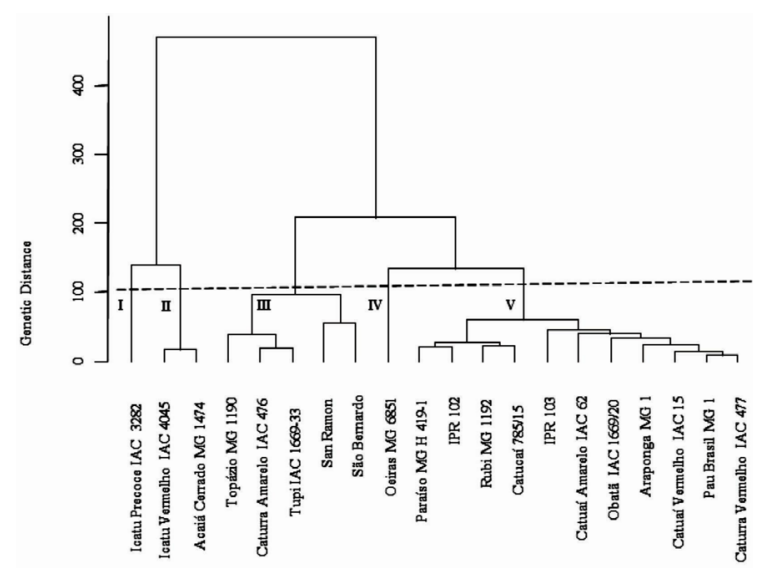

Figure 1 - Genetic dissimilarity among 20 cultivars of arabica coffee grown in nutrient solution with low potassium $\left(1.5 \mathrm{mmol} \mathrm{L}^{-1}\right)$. Dendrogram obtained by UPGMA based on 15 quantitative traits using the Mahalanobis distance (cophenetic correlation: 0.85).

The most similar pairs of cultivars were Caturra Vermelho IAC 477 with cultivars Pau Brasil MG1, Araponga MG1 and Catuaí Vermelho IAC 15; Icatu Vermelho IAC 4045 and Acaiá Cerrado MG 1474; Caturra Amarelo IAC 476 and Tupi IAC 1669-33; Catuaí Vermelho IAC 15 and Pau Brasil MG1 (Figure 1). Most of these combinations involved high K-efficient cultivars (Table 2). In selecting materials for crossing it is recommended that both be in separate groups to increase the heterosis effect in segregating generations (Cruz; Regazzi; Carneiro, 2012).

The UPGMAcluster analysis (Cruz; Regazzi; Carneiro, 2012) indicated five distinct clusters with cophenetic correlation of 0.85 (Figure 1). This method has also been effective in discriminating genotypes based on agronomic traits of both Arabica coffee (Pedrosa et al., 2013, Macedo; Lopes, 2008) and Robusta coffee (Fonseca et al. 2006; Ivoglo et al., 2008).
Group I was formed by cultivar Icatu Precoce IAC 3282 (Figure 1). This cultivar is characterized by tall stature, early ripening and tolerance to rust (Carvalho, 2008). It showed high $\mathrm{K}$ translocation efficiency, but Intermediate K utilization efficiency (Table 2). This result was opposite to that reported by Amaral et al., 2011a, where cultivar Icatu Precoce IAC 3282 was the most efficient in $\mathrm{N}, \mathrm{S}$ and $\mathrm{Zn}$ utilization for branch production when grown with low-potassium fertilization in association with other nutrients. It also showed high agronomic efficiency under the same conditions (Amaral et al., 2011b).

Cultivars Icatu Vermelho IAC 4045 and Acaiá Cerrado MG 1474 formed group II (Figure 1). These cultivars showed the highest translocation K efficiency, but were less efficient in $\mathrm{K}$ utilization for biomass conversion (Table 2). Opposite behavior was observed for cultivar Acaiá grown in low $\mathrm{N}, \mathrm{P}$ and $\mathrm{K}$ rates, standing out for the high efficiency in root and stem production (Amaral et al., 2011a).

Group III consisted of five cultivars: Topázio MG 1190, Tupi IAC 1669-33, Caturra Amarelo IAC 476, San Ramon and São Bernardo (Figure 1). Most of these cultivars showed lower means for the agronomic traits and were most efficient only for $\mathrm{K}$ translocation (Tables 2 and 3). In this group, the last three cultivars are ancient and have been little improved for agronomic traits. Cultivar Oeiras MG 6851 formed group IV (Figure 1). It belongs to Catimor germplasm and is characterized by short stature, high vegetative vigor and resistance to coffee rust (Carvalho, 2008). It showed high $\mathrm{K}$ translocation efficiency, but low efficiencies of rooting, absorption and biomass production (Table 3 ).

Group V comprised the largest number of cultivars, being all of low stature and shorter internode length, but most presented the highest means for number of leaves, number of nodes, stem diameter, leaf area, dry matter production of root, stem and leaf (Table 2). This group stood out for having the largest number of cultivars with $\mathrm{K}$ utilization efficiency for production of root dry matter and biomass, although with lower efficiencies in absorption and translocation (Table 3 ). It is noteworthy that these cultivars have at least one parent in common (Table 1), which may have contributed to the lower variability found among them.

The canonical analysis showed that the first two variables represented $88.82 \%$ of the total cumulative variation (Figure 2). The first canonical variable (CV 1) explained $49.60 \%$ of the variation, while the second canonical variable (CV 2) explained $39.22 \%$, which was satisfactory for the two dimensional graph representation (Tabela 4). This also allows for satisfactorily explaining the variability among genotypes (Cruz; Regazzi; Carneiro, 2012). This method was also effective in identifying the most divergent Conilon genotypes (Fonseca et al., 2006). 


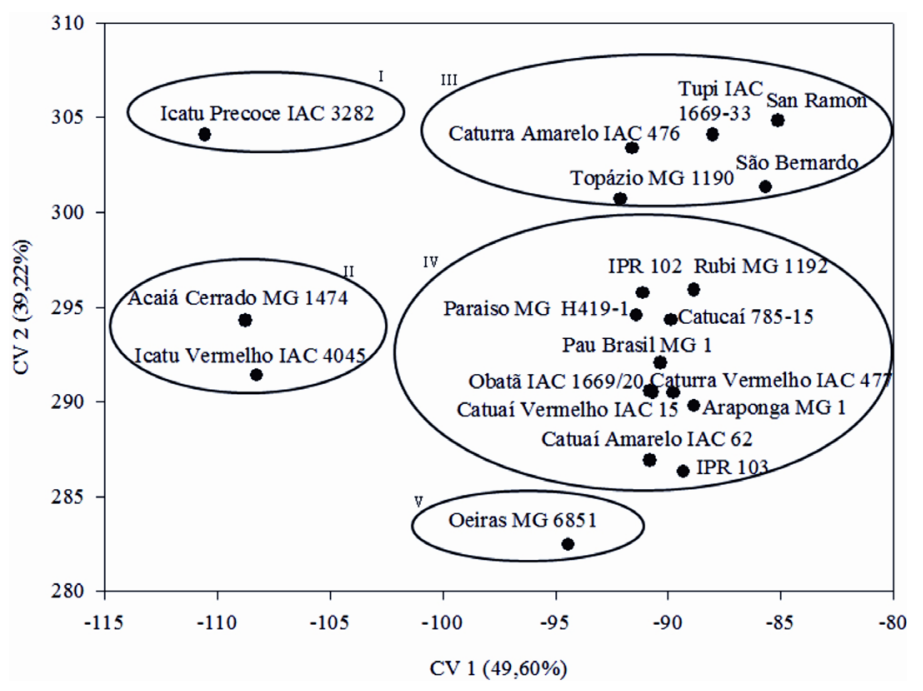

Figure 2 - Scores plotted along the first and second canonical variable axes (CV 1 and CV 2) for the 15 traits studied in 20 cultivars of arabica coffee grown in nutrient solution with low potassium rate $\left(1.5 \mathrm{mmol} \mathrm{L}^{-1}\right)$.

Table 4 - Cumulative variance (\%) by the canonical variables (CVi) of 15 characteristics evaluated for coffee cultivars grown in nutrient solution with low dose of potassium $\left(1.5 \mathrm{mmol} \mathrm{L}^{-1}\right)$.

\begin{tabular}{cccccccccccc}
\hline $\begin{array}{c}\text { Cumulative Variance } \\
(\%)\end{array}$ & $\mathrm{CV}_{1}$ & $\mathrm{CV}_{2}$ & $\mathrm{CV}_{3}$ & $\mathrm{CV}_{4}$ & $\mathrm{CV}_{5}$ & $\mathrm{CV}_{6}$ & $\mathrm{CV}_{7}$ & $\mathrm{CV}_{8}$ & $\mathrm{CV}_{9}$ &.. & $\mathrm{CV}_{15}$ \\
\cline { 2 - 11 } & 49,69 & 88,82 & 93,89 & 95,60 & 97,04 & 97,98 & 98,66 & 99,07 & 99,36 &.. & 100,00 \\
\hline
\end{tabular}

The mean comparison analysis along with the clustering by the UPGMA (Figure 1) and canonical variables (Figure 2) allowed the identification of the variability among the cultivars grown with low potassium level. This identification will provide tools for selecting contrasting genotypes that can assist in determining the genetic control of these traits, allowing a more appropriate strategy for the identification of superior arabica coffee cultivars. In selecting materials for crossing is recommended that both be in separate groups to increase the heterosis effect in segregating generations (Cruz; Regazzi; Carneiro, 2012).

\section{CONCLUSIONS}

There is genetic variability among coffee cultivars grown in an environment with low availability of potassium.

Hybridizations between the cultivar Icatu Precoce IAC 3283 with cultivars Catuaí Amarelo IAC 62, Araponga MG1, Caturra Vermelho IAC 477, Catuaí Vermelho IAC 15, Rubi MG 1192 and Catucaí 785/15, and between the cultivar Tupi IAC 1669-33 with cultivars Icatu Vermelho IAC 4045, Acaiá Cerrado MG 1474 and
Oeiras MG 6851 are the most promising for obtaining segregating populations or heterotic hybrids in breeding programs aiming at more efficiency in potassium utilization.

\section{ACKNOWLEDGMENTS}

We thank the Consórcio Brasileiro de Pesquisa e Desenvolvimento do Café (CBP\&D-Café) for the financial support to this research. The Conselho Nacional de Desenvolvimento Cientítico e Tecnológico (CNPq), the Fundação de Amparo à Pesquisa do Estado de Minas Gerais (FAPEMIG) and the Fundação de Amparo à Pesquisa do Estado do Rio de Janeiro (FAPERJ) for the grants awarded to the authors.

\section{REFERENCES}

AMARAL, J. F. et al. Eficiência de utilização de nutrientes por cultivares de cafeeiro. Ciência Rural. 41(4):621-629, 2011a.

. Produtividade e eficiência de uso de nutrientes por cultivares de cafeeiro. Coffee Science. 6(1):65-74, 2011b. 
CARVALHO, C.H. S. de (Ed.). Cultivares de café: origem, características e recomendações. 1. ed. Brasília: Embrapa Café, 2008. 334p.

CRUZ, C.D.; REGAZZI, A.J.; CARNEIRO, P.C.S. Modelos biométricos aplicados ao melhoramento genético. Viçosa: Editora UFV, 2012. 514p.

CLEMENTE, J.M. et al. Effect of $\mathrm{N}$ and $\mathrm{K}$ doses in nutritive solution on growth, production and coffee bean size. Revista Ceres. 60(2):279-285, 2013.

CRUZ, C.D. GENES - a software package for analysis in experimental statistics and quantitative genetics. Acta Scientiarum. Agronomy. 35(05):271-276, 2013.

DIAS, F.P. et al. Caracterização de progênies do cafeeiro (Coffea arabica L.) selecionadas em Minas Gerais: III Divergência genética. Revista Ceres. 52(299):101-114, 2005.

FAO. FAOSTAT Database Query. Available in $<\mathrm{http}$ :// faostat.fao.org/>. Acess in: March, 02, 2013.

FONSECA, A.F.A. et al. Divergência genética em café conilon. Pesquisa Agropecuária Brasileira. 41(4):599$605,2006$.

GRAHAM, R. D. Breeding for nutritional characteristics in cereals. In: TINKER, P. B.; LAUCHLI, A. Advances in Plant Nutrition. New York: Praeger. 1984. p.57-102.

GABELMAN, W.H.; GERLOFF, G.C. The search for and interpretation of genetic controls that enhance plant growth under deficiency levels of a macronutrient. Plant Soil.72(2/3):335-350, 1983.

GUEDES, J.M. et al. Divergência genética entre cafeeiros do germoplasma Maragogipe. Bragantia. 72(2):127-132, 2013.

GUIMARÃES, P.T.G. et al. Nutrição do cafeeiro e sua relação com a qualidade do café. Informe Agropecuário. 32(261):39-51, 2011.

HOAGLAND, D.R.; ARNON, D. I. The water culture method for growing plants without soils. Berkeley: California Agricultural Experimental Station, 1950. $347 p$.
IVOGLO, M.G. et al. Divergência genética entre progenies de café robusta. Bragantia. 67(4):823-831, 2008.

LAVIOLA, B.G. et al. Influência da adubação na formação de grãos mocas e no tamanho de grãos de café (Coffea arabica L.). Coffee Science. 1(1):36-42, 2006.

MACEDO, C.M.P.; LOPES, J.C. Qualidade fisiológica de semente de café arábica na presença de alumínio. Revista Brasileira de Sementes. 30(1):66-73, 2008.

MARENCO, R.A.; LOPES, N.F. Fisiologia Vegetal: Fotossíntese, respiração, relações hídricas e nutrição mineral. Viçosa: Editora UFV. 2005. 451p.

MARSCHNER, H. Mineral nutrition of higher plants. 2. ed. New York: Academic Press. 2012. 889p.

MAPA. Ministério da Agricultura, Pecuária e Abastecimento. Produção de grãos. Brasília, Available in: http:<//www.agricultura.gov.br/>. Acess in: november, 29. 2012.

PEDROSA, A.W. et al. Caracterizing zinc use efficiency in varieties of arabica coffee. Acta Scientiarum.

Agronomy. 35(3):343-348, 2013.

SIDDIQI, M.Y.; GLASS, A.D.M. Utilization index: a modified approach to the estimation and comparison of nutrient utilization efficiency in plants. Journal of Plant Nutrition. 4(3): 289-302, 1981.

ROCHA, R.B. et al. Caracterização e uso da variabilidade genética de banco ativo de germoplasma de Coffea canephora Pierre ex Froehner. Coffee Science. 8(4):478-485, 2013.

SILVA, F.L. et al. Integração de dados quantitativos e multicategóricos na determinação da divergência genética entre acessos de cafeeiro. Bragantia. 72(3):224-229, 2013.

SINGH, D. The relative importance of characters affecting genetic divergence. Indian Journal of Genetics and Plant Breeding. 41(2):237-245, 1981

TEIXEIRA, A.L. et al. Análise e componentes principais em caracteres morfológicos de café arábica em estádio juvenil. Coffee Science. 8(2):205-210, 2013.

Ciênc. Agrotec., Lavras, v.39, n.1, p.23-31, jan./fev., 2015 
TOMAZ, M.A. et al. Porta-enxertos afetando o desenvolvimento de plantas de Coffea arabica $\mathrm{L}$. Ciência Rural. 35(3):570-575, 2005.
Diferenças genéticas na eficiência de absorção, na translocação e na utilização de K, Ca e Mg em mudas enxertadas de cafeeiro. Ciência Rural. 38(6):1540-1546, 2008. 